\title{
Radiocarbon
}

1987

\section{RADIOCARBON AGE ANOMALIES IN SHELL CARBONATE OF LAND SNAILS FROM SEMI-ARID AREAS}

\author{
GLENN A GOODFRIEND
}

Isotope Department, Weizmann Institute of Science 76100 Rehovot, Israel

\begin{abstract}
Radiocarbon age anomalies, resulting from ingestion of old carbonate, were measured in shell carbonate of live-collected snails from arid and semi-arid areas of Israel and the West Bank. The age anomalies were found to be similar to those in land snails from other climatic regions and averaged ca $1600 \mathrm{yr}$ in Trochoidea seetzeni, $2200 \mathrm{yr}$ in Sphincterochila spp, $800 \mathrm{yr}$ in Levantina sp, and $1700 \mathrm{yr}$ in coastal dune species. The differences are associated with ecological differences among taxa. The uncertainties of the age anomalies average several hundred years within each group. This renders radiocarbon dates of late Holecene snails relatively imprecise, whereas it has almost no effect on the age uncertainties of relatively old samples (ie, those with large errors of measurement). Procedures for correction for fractionation are discussed.
\end{abstract}

\section{INTRODUCTION}

Land snails have a habit that is unfortunate for one wishing to radiocarbon date their shells: they ingest calcium carbonate, which is digested to $\mathrm{CO}_{2}$, dissolved in the body fluids, and subsequently incorporated into their shells. Since the carbonate available to land snails is generally old (depleted in ${ }^{14} \mathrm{C}$ ), it confers an age anomaly to the shell carbonate (Goodfriend \& Stipp, 1983). This age anomaly has been shown to occur in land snails from temperate regions (Tamers, 1970; Burleigh \& Kerney, 1982; Evin et al, 1980 ) as well as tropical regions (Tamers, 1970; Goodfriend \& Stipp, 1983) and has a maximum of ca 3000 yr (Goodfriend \& Stipp, 1983). The age anomaly in fossil land snail shell carbonate can be corrected for by estimation of the age anomaly in live-collected shells of the same or similar species from a similar substrate. However, the variability of the age anomaly may result in dates with low precision (Goodfriend \& Stipp, 1983).

In the present study, ${ }^{14} \mathrm{C}$ concentrations in live-collected land snails from the Negev Desert in Israel and Judean Desert in the West Bank (mean annual rainfall $80-200 \mathrm{~mm}$ ) and from the Mediterranean coastal dunes of Israel (rainfall $400-500 \mathrm{~mm}$ ) were analyzed in order to estimate the carbonate age anomalies and their variabilities. For most of the species, calcium carbonate is available from sediments-loess (or redeposited loessial sediments) in the case of the desert snails and sand in the case of the dune snails. Levantina sp lives on limestone, which may serve as a carbonate source.

\section{MATERIALS AND METHODS}

Most of the land snail shells analyzed here were collected before thermonuclear bomb tests raised atmospheric ${ }^{14} \mathrm{C}$ to unnatural levels (ca 1960). 
Such material is preferred since precise estimates of age anomalies require precise information on atmospheric ${ }^{14} \mathrm{C}$ at the time of shell formation. Since the early $1960 \mathrm{~s}$, atmospheric ${ }^{14} \mathrm{C}$ levels have been decreasing steadily (currently at the rate of ca $2 \% / \mathrm{yr}$ ). For snails that live more than one year, the exact age of the snail must be known in order to estimate atmospheric levels at the time of shell deposition. Furthermore, for species with continuous growth, atmospheric carbon may be integrated over many years. Analysis of postbomb samples was therefore limited to species that have annual life cycles (Theba pisana and Xeropicta vestalis) (Heller, 1982; Heller \& Volokita, 1981) and to juveniles ( $\leq 1 \mathrm{yr}$ old) of multi-annual species (Trochoidea seetzeni, sample RT-675). Radiocarbon measurements of the annual species were provided by Dr A Kaufmann of the Weizmann Institute of Science.

Shells were scrubbed thoroughly on the outside with a toothbrush and broken open; the inner whorls were then removed and the shells scrubbed on the inside. Sonication was used in some cases to remove adhering organic material. The cleaned shells were briefly washed with dilute HCL, then rinsed with distilled water and dried. The shells were reacted with HCL under vaccum and the $\mathrm{CO}_{2}$ generated was collected and converted through acetylene to ethane. ${ }^{14} \mathrm{C}$ was measured by gas counting (Carmi, Noter \& Schlesinger, 1971; Carmi, in press).

Age anomalies were calculated in the following manner. The relative ${ }^{14} \mathrm{C}$ activity of shell carbonate (uncorrected for fractionation) was calculated as the ratio of the measured ${ }^{14} \mathrm{C}$ activity (corrected for decay of ${ }^{14} \mathrm{C}$ between the time of collection and the time of measurement) to the estimated ${ }^{14} \mathrm{C}$ activity of atmospheric $\mathrm{CO}_{2}$ at the time of shell formation.

\section{CORRECTION FOR FRACTIONATION}

In order to correct the relative ${ }^{14} \mathrm{C}$ activity for isotopic fractionation, we need to know 1) the proportion of shell carbonate carbon derived from non-carbonate sources (ie, from plant matter and atmospheric $\mathrm{CO}_{2}$ ) and 2) the $\delta^{13} \mathrm{C}$ of this fraction. This is because the correction for fractionation applies only to this fraction and not to that derived from ingested carbonate (Goodfriend \& Hood, 1983) (assuming no fractionation between dissolved bicarbonate and the shell carbonate precipitated from it; see Goodfriend \& Hood (1983) for discussion of this assumption).

The proportion of non-carbonate-derived carbon is approximately equal to the relative ${ }^{14} \mathrm{C}$ activity, assuming the carbonate is devoid of ${ }^{14} \mathrm{C}$ (not strictly true-see discussion below). Formally,

$$
\mathrm{A}_{\mathrm{m}} \approx \mathrm{P}_{\mathrm{nc}}\left(\mathrm{A}_{\mathrm{a}}\right)+\left(1-\mathrm{P}_{\mathrm{nc}}\right)\left(\mathrm{A}_{\mathrm{c}}\right),
$$

where $A_{m}=$ measured ${ }^{14} \mathrm{C}$ activity of shell (decay-corrected), $P_{n c}=$ proportion of shell carbonate not derived from a carbonate source, $\mathrm{A}_{\mathrm{a}}=$ contemporary atmospheric ${ }^{14} \mathrm{C}$ activity (corrected for fractionation), and $\mathrm{A}_{\mathrm{c}}={ }^{14} \mathrm{C}$ activity of ingested carbonate. This result is only approximate since the $A_{m}$ value is not (yet) corrected for fractionation. If $A_{c}=0$, then

$$
\mathrm{P}_{\mathrm{nc}} \approx \mathrm{A}_{\mathrm{m}} / \mathrm{A}_{\mathrm{a}}
$$

which is the relative ${ }^{14} \mathrm{C}$ activity of the shell. 
The measured $\delta^{13} \mathrm{C}$ of the shell carbonate represents a mixture of the $\delta^{13} \mathrm{C}$ of the carbonate-derived and non-carbonate-derived carbon:

$$
\delta^{13} \mathrm{C}_{\mathrm{m}}=\mathrm{P}_{\mathrm{nc}}\left(\delta^{13} \mathrm{C}_{\mathrm{nc}}\right)+\left(1-\mathrm{P}_{\mathrm{nc}}\right)\left(\delta^{13} \mathrm{C}_{\mathrm{c}}\right)
$$

where $\delta^{13} \mathrm{C}_{\mathrm{m}}$ is the measured ${ }^{13} \mathrm{C}$ value of the shells, and $\delta^{13} \mathrm{C}_{\mathrm{nc}}$ and $\delta^{13} \mathrm{C}_{\mathrm{c}}$ are the ${ }^{13} \mathrm{C}$ values of the non-carbonate and carbonate fractions, respectively. Rearranging this to solve for $\delta^{13} \mathrm{C}_{\mathrm{nc}}$, we get

$$
\delta^{13} \mathrm{C}_{\mathrm{nc}}=\frac{\delta^{13} \mathrm{C}_{\mathrm{m}}-\left(1-\mathrm{P}_{\mathrm{nc}}\right)\left(\delta^{13} \mathrm{C}_{\mathrm{c}}\right)}{\mathrm{P}_{\mathrm{nc}}} .
$$

Substituting for $\mathrm{P}_{\mathrm{nc}}$ from Equation 2, we get

$$
\delta^{13} \mathrm{C}_{\mathrm{nc}} \approx \frac{\delta^{13} \mathrm{C}_{\mathrm{m}}-\left(1-\mathrm{A}_{\mathrm{m}} / \mathrm{A}_{\mathrm{a}}\right)\left(\delta^{13} \mathrm{C}_{\mathrm{c}}\right)}{\mathrm{A}_{\mathrm{m}} / \mathrm{A}_{\mathrm{a}}} .
$$

The standard formula for correction for fractionation (Stuiver \& Polach, 1977) can be expressed as

$$
\mathrm{A}_{\mathrm{m}}^{\prime}=\mathrm{A}_{\mathrm{m}}\left(1-\frac{2\left(\delta^{13} \mathrm{C}_{\mathrm{nc}}+25\right)}{1000}\right),
$$

where $\mathrm{A}_{\mathrm{m}}^{\prime}$ is the ${ }^{14} \mathrm{C}$ activity corrected for fractionation. Substituting for $\delta^{13} \mathrm{C}_{\mathrm{nc}}$ from Equation 5, we have

$$
\mathrm{A}_{\mathrm{m}}^{\prime} \approx \mathrm{A}_{\mathrm{m}}\left(1-\frac{2\left(\frac{\delta^{13} \mathrm{C}_{\mathrm{m}}-\left(1-\mathrm{A}_{\mathrm{m}} / \mathrm{A}_{\mathrm{a}}\right)\left(\delta^{13} \mathrm{C}_{\mathrm{c}}\right)}{\mathrm{A}_{\mathrm{m}} / \mathrm{A}_{\mathrm{a}}}+25\right)}{1000}\right) .
$$

If $\delta^{13} \mathrm{C}_{\mathrm{c}}=0$ (not always true-see below), then Equation 7 simplifies to

$$
\mathrm{A}_{\mathrm{m}}^{\prime} \approx \mathrm{A}_{\mathrm{m}}\left(1-\frac{2\left(\frac{\delta^{13} \mathrm{C}}{\mathrm{A}_{\mathrm{m}} / \mathrm{A}_{\mathrm{a}}}+25\right)}{100()}\right) \text {. }
$$

Note that if no shell carbonate is derived from ancient carbonate sources, then $\mathrm{A}_{\mathrm{m}}=\mathrm{A}_{\mathrm{a}}$ (ie, the shells show no age anomaly) and the expression reduces to the standard correction for fractionation.

This new, approximately corrected estimate of ${ }^{14} \mathrm{C}$ activity, $\mathrm{A}_{\mathrm{m}}^{\prime}$, is then substituted for the original uncorrected activity, $A_{m}$, in Equation 8 (or 7 ) to obtain a new, more accurate estimate, $\mathrm{A}_{\mathrm{m}}^{\prime \prime}$. This iterative process is continued until the ${ }^{14} \mathrm{C}$ activity converges to a constant value. In practice, the values converge rapidly, and only three iterations (estimation of $\mathrm{A}_{\mathrm{m}}^{\prime \prime \prime}$ ) are required to estimate the corrected ${ }^{14} \mathrm{C}$ activity to $0.01 \%$ modern. The relative ${ }^{14} \mathrm{C}$ activity is then estimated as $\mathrm{A}_{\mathrm{m}}^{\prime \prime \prime} / \mathrm{A}_{\mathrm{a}}$.

If $\delta^{13} \mathrm{C}_{\mathrm{c}} \approx \delta^{13} \mathrm{C}_{\mathrm{m}}$, then $\delta^{13} \mathrm{C}_{\mathrm{m}} \approx \delta^{13} \mathrm{C}_{\mathrm{nc}}$, and the correction for fractionation can be made (from Eq 6 ) as:

$$
\mathrm{A}_{\mathrm{m}}^{\prime}=\mathrm{A}_{\mathrm{m}}\left(1-\frac{2\left(\delta^{13} \mathrm{C}_{\mathrm{m}}+25\right)}{1000}\right)
$$

which requires no interation for solution. 
The age anomalies of the shells were calculated from the depletion in relative ${ }^{14} \mathrm{C}$ activity $\left(1-\mathrm{A}_{\mathrm{m}}^{\prime \prime \prime} / \mathrm{A}_{\mathrm{a}}\right)$, which is converted to years by the usual formula.

\section{AGE ANOMALIES IN MODERN SNAILS}

Age anomalies in the 14 samples analyzed range from ca 700 to 2800 yr (Table 1), similar to the anomalies in land snails from limestone areas in the humid tropics (Goodfriend \& Stipp, 1983) and moist temperate zone (Burleigh \& Kerney, 1982). These results further support previous findings that indicate a maximum carbonate age anomaly of ca $3000 \mathrm{yr}$ in land snails (Goodfriend \& Stipp, 1983).

Differences in average age anomalies are seen among taxa: Sphincterochila spp have relatively large age anomalies, whereas Levantina sp has a small age anomaly, with Trochoidea seetzeni and the two coastal dune species having intermediate values. These differences correspond closely to the ecology of the snails. Sphincterochila spp eat the alga and lichen crusts on the surface of the sediments and consequently ingest very large amounts of carbonate-containing sediment, which would lead to larger age anomalies. All of the species showing intermediate values live on plants (although $T$ seetzeni may also live under rocks) and descend to the ground to feed on dead plant material when conditions are moist. Gut content analysis of $T$ seetzeni indicates that it occasionaly ingests sediments. Levantina, showing the smallest age anomalies, lives on limestone rocks and feeds on dead plant material on the ground. Gut content analysis has failed to reveal sediment. Carbonate uptake apparently occurs by dissolution and subsequent uptake of carbonate by the foot, which in some land snails is known to produce acidic secretions (Frick, 1965). This habit of these snails is apparently responsible for creation of large pits observed in limestone rocks (Danin, 1986). Carbonate might also occasionally be scraped from rocks and ingested by these snails. It is not clear why Levantina should have small age anomalies but a possible explanation is that the continual availability of calcium carbonate does not require the snails to take up as large an amount as in the plant-dwelling species, to which it is available only when on the ground feeding.

Within these ecological groupings of snails, variability of the age anomalies (as measured by their standard deviation) is relatively low, ca 200-500 $\mathrm{yr}$ (Table 2). The variance $\left[(\mathrm{SD})^{2}\right]$ of the age anomalies within a group is the sum of the variance due to the analytical uncertainty of the measurements plus the variance due to real differences in age anomalies among samples. Since the error of measurement is different for different samples, the residual variance among samples cannot be calculated exactly. However, the mean error of measurement within the group can be used to calculate the residual variation among samples approximately. Alternatively, the maximum possible variation among samples can be estimated by choosing the lowest error of measurement within the group as representative of each sample. For $T$ seetzeni, the error introduced by the variability of the age anomaly is calcualted as ca \pm 230 (Table 2) and is not more than $250 \mathrm{yr}$, whereas for Sphincterochila spp it is ca \pm 490 and not more than $500 \mathrm{yr}$. For 
${ }^{14} \mathrm{C}$ Age Anomalies in Land Snails

163

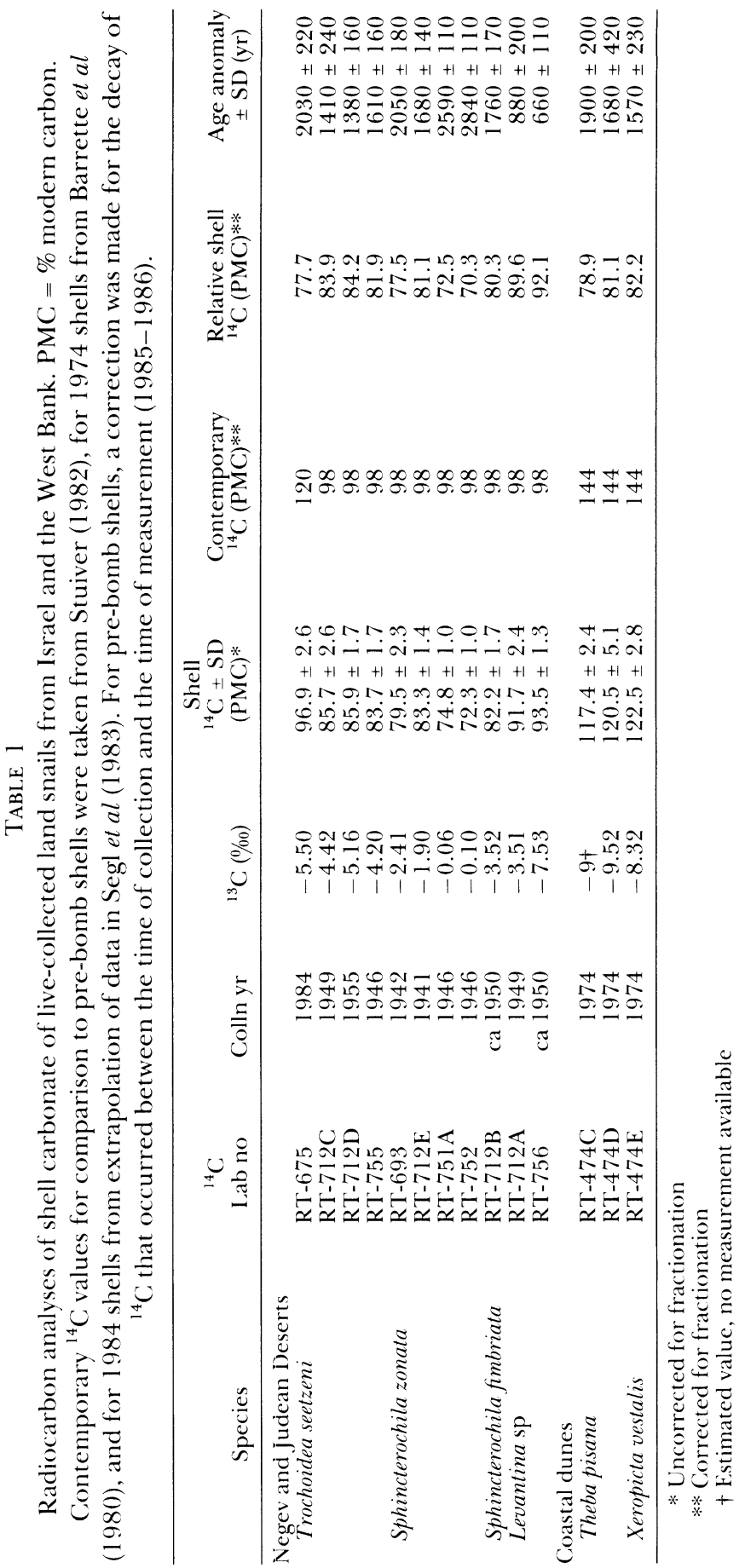




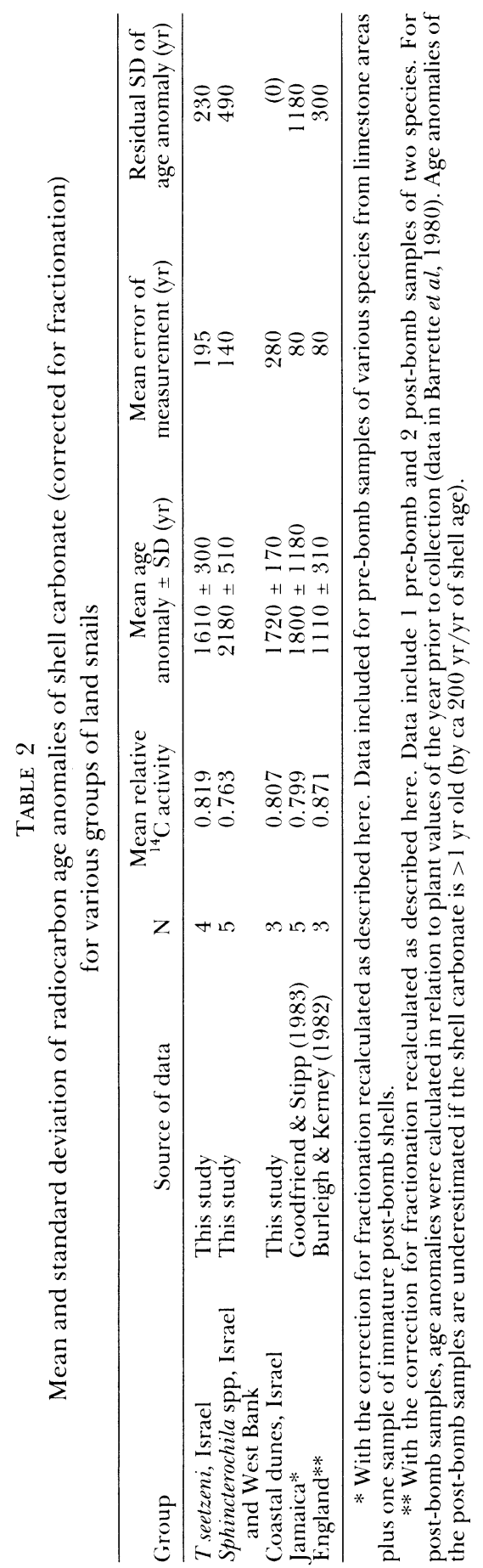


the coastal dune snails, the variation among samples is actually less than the error of measurement of any of the samples, thus indicating no measurable variability in age anomalies among samples. All of these estimates must be considered approximate because of the small number of samples (3-5) on which they are based.

\section{CORRECTION FOR FRACTIONATION: EVALUATION OF ASSUMPTIONS}

As discussed above, the procedure for correction for fractionation assumes that the carbonate source that produces the shell carbonate age anomaly has no ${ }^{14} \mathrm{C}$ and has $\delta^{13} \mathrm{C}=0$ (typical values for limestones) in the simplified version ( $\mathrm{Eq} 8$ ). The effect that deviations from these assumed values have on the calculated ages is now considered.

If the old carbonate source has some ${ }^{14} \mathrm{C}$ activity, then the proportion by which the relative shell ${ }^{14} \mathrm{C}$ activity is depleted is an underestimate of the proportion of shell carbonate derived from old carbonate. The correction for fractionation is therefore correspondingly less. Carbonate in sand collected from the surface at the same site as the coastal dune snail samples RT-474D and $\mathrm{E}$ was found to have $\mathrm{a}^{14} \mathrm{C}$ activity of $4.1 \pm 0.5 \%$ modern (RT$720)$, corrected for fractionation. The difference between this and $0 \%$ modern is negligible for calculations of the proportion of non-carbonatederived shell carbonate for correction for fractionation. However, carbonate in loessial sediments in the Negev shows significant ${ }^{14} \mathrm{C}$ activity. A sample of the surface crust carbonate from the same site as $S$ zonata sample RT-693 gave a value of $27.8 \pm 0.5 \%$ modern (RT-719). In order to produce the $22.9 \%$ depletion in ${ }^{14} \mathrm{C}$ measured in this $S$ zonata sample, $31.7 \%$ of its shell carbonate would have to have been derived from loess carbonate. This reduces the correction for fractionation for the non-carbonate-derived portion of the shell carbonate from $3.6 \%$ to $3.0 \%$, equivalent to a $50-y r$ increase in the estimated ${ }^{14} \mathrm{C}$ age or decrease in the estimated age anomaly. This amount is small in relation to the uncertainty of the age anomaly of a sample of any of the species. Other Negev surface crust samples show similar $(28.0 \pm 0.6 \%$ modern; RT-785C) or lower $(13.4 \pm 0.5 \%$ modern; RT$785 \mathrm{~A}){ }^{14} \mathrm{C}$ activity.

The $\delta^{13} \mathrm{C}$ of the surface crust carbonate may deviate from the value of $0 \%$ used in the age anomaly calculations because of pedogenic alteration (reprecipitation of carbonate). In the Negev, surface crust carbonate $\delta^{13} \mathrm{C}$ ranges from $0 \%$ in drier areas (receiving $100 \mathrm{~mm}$ mean annual rainfall) to $-6 \%$ in wetter areas $(300 \mathrm{~mm}$ rainfall) (Magaritz \& Goodfriend, unpub data). To examine the effect of values of $\delta^{13} \mathrm{C}_{c}<0 \%$ on the age anomaly estimates, $\delta^{13} \mathrm{C}_{\mathrm{nc}}$ was recalculated from Equation 3 using the extreme value of $\delta^{13} \mathrm{C}_{\mathrm{c}}=-6^{0} \% 0$. For the $S$ zonata sample RT-752, with the very high $\delta^{13} \mathrm{C}_{\mathrm{m}}$ of $-0.1 \%$, the use of the extreme value of $\delta^{13} \mathrm{C}_{\mathrm{c}}$ increases the calculated age anomaly by ca $40 \mathrm{yr}$, whereas for the $T$ seetzeni sample RT- 675 , with a low $\delta^{13} \mathrm{C}_{\mathrm{m}}$ of $-5.50 \%$, the age anomaly is increased by ca $20 \mathrm{yr}$. As with the assumption of no ${ }^{14} \mathrm{C}$ activity of the old carbonate source, deviation from assumed value of $\delta^{13} \mathrm{C}_{\mathrm{c}}=0$ makes little difference to the age anomaly calculations and is in the opposite direction of that due to ${ }^{14} \mathrm{C}$ activity $>0$. Values of $\delta^{13} \mathrm{C}_{\mathrm{c}}<0$ should occur in pedogenetically altered carbonates. Such car- 
bonates will also tend to show ${ }^{14} \mathrm{C}$ activity $>0$. Thus the small errors in calculated shell age anomalies due to each will tend to cancel each other.

\section{RADIOCARBON AGE CORRECTIONS IN FOSSIL LAND SNAIL SHELLS}

From data on the relative ${ }^{14} \mathrm{C}$ activity of live-collected samples, estimates of the mean age anomaly and its standard deviation and the mean proportion of shell carbonate derived from non-carbonate sources $\left(A_{m} / A_{a}\right)$ can be made, as above (Table 2). These correction factors may then be applied to apparent radiocarbon ages of fossil specimens of the same or similar species from a similar substrate. Equation 7, 8, or 9 is used (according to the assumptions concerning $\delta^{13} \mathrm{C}_{\mathrm{c}}$ ) to obtain the fractionation-corrected apparent age of the fossils. The age anomaly is then substracted from the apparent age to obtain the best estimate of the true age of the fossils.

However, a possible problem should be borne in mind: carbonate substrates that have some ${ }^{14} \mathrm{C}$ activity (ie, that contain some non-ancient carbon) may change their apparent ${ }^{14} \mathrm{C}$ ages over time. Consequently, the carbonate age anomalies of land snail shells resulting from ingestion of these materials might vary over time. In such a case, a correction for the age anomaly based on modern shells may not be strictly applicable to fossils. Substrate ${ }^{14} \mathrm{C}$ activity will tend to decrease over time as a result of aging (decay of ${ }^{14} \mathrm{C}$ ) or it may increase as a result of addition of new carbonate. In loessial sediments in the Negev new carbonate is added as a result of pedogenic activity (dissolution-reprecipitation of carbonate) (Magaritz, 1986). It is not clear how the ${ }^{14} \mathrm{C}$ activity of the surface of the loess may change over time as a result of variation in the intensity of pedogenic activity.

The true standard deviation of the corrected age estimates of fossils can be calculated as the square root of the sum of the variance $\left(\mathrm{SD}^{2}\right)$ reported by the laboratory plus the residual variance of the age anomaly for the taxon, as calculated above. As discussed above, the standard deviation of this latter term varies between ca 200-500 yr for the semi-arid and arid zone land snail taxa analyzed here. English land snails (Burleigh \& Kerney, 1982) have a similar variation in their age anomalies (Table 2). However, Jamaican land snails from limestone areas show considerably more variable age anomalies. This may be in part the result of ecological diversity among the taxa included in the analysis, eg, both rock-scrapers and leaf litter eaters are included.

Of the two error terms that together contribute to the uncertainty of the estimated age of a fossil (ie, error of measurement and uncertainty of age anomaly), the larger of the two terms will greatly predominate over the smaller in the combined error. For relatively young fossil material, it will be the uncertainty in the age anomaly that predominates. In older material and/or small samples in which the error of measurement exceeds the several hundred years of the age anomaly uncertainty, the error of measurement will largely determine the uncertainty of the corrected age. Thus, for older deposits, land snail shell carbonate can give radiocarbon dates as precise as preferred materials such as charcoal or wood, given appropriate corrections for age anomaly and fractionation. For late Holocene samples from carbonate areas, shell carbonate radiocarbon analysis will not yield 
precise age estimates. For such material, amino acid racemization/epimerization dating (Goodfriend, in press) may give more precise results. Accelerator mass spectrometer radiocarbon dating of shell organic matter might also give more precise dates but problems have been encountered with this method as applied to marine shells (Gillespie, Hedges \& Humm, 1986).

\section{ACKNOWLEDGMENTS}

The author is indebted to Aaron Kaufman for providing the radiocarbon data on the coastal dune snails. Henk Mienis kindly made available prebomb snail shells from the collection of the Zoology Museum, Hebrew University, Jerusalem; without these, the present study would not have been possible. Israel Carmi, Aaron Kaufman, and an anonymous reviewer provided useful comments on the manuscript.

\section{REFERENCES}

Barrette, L, Lasalle, P, Martel, Y and Samson, C, 1980, Variation of ${ }^{14} \mathrm{C}$ in oats grown from 1957 to 1978 in Quebec, in Stuiver, $M$ and Kra, R S, eds, Internatl ${ }^{14} \mathrm{C}$ conf, 10 th, Proc: Radiocarbon, v 22, no. 2, p 410-414.

Burleigh, R and Kerney, M P, 1982, Some chronological implications of a fossil molluscan assemblage from a Neolithic site at Brook, Kent, England: Jour Archaeol Sci, v 9, p 2938.

Carmi, I, 1987, Rehovot radiocarbon measurements III: Radiocarbon, v 29, no. 1, p 100114.

Carmi, I, Noter, Y and Schlesinger, R, 1971, Rehovot radiocarbon measurements I: Radiocarbon, v 13, no. 2, p 181-195.

Danin, A, 1986, Patterns of biogenic weathering as indicators of palaeoclimates in Israel: Royal Soc Edinburgh Proc, v 89B, p 243-253.

Evin, J, Marechal, J, Pachiaudi, C and Puissegur, J J, 1980, Conditions involved in dating terrestrial shells, in Stuiver, M and Kra, R S, eds, Internatl ${ }^{14} \mathrm{C}$ conf, 10 th, Proc: Radiocarbon, v 22, no. 2, p 545-555.

Frick, W, 1965, Der Kalziumstoffwechsel bei Helix pomatia unter dem Einfluss wechselnder Kohlensäureatmosphären: Mitt Zool Mus Berlin, v 41, p 95-120.

Goodfriend, G A, in press, Evaluation of amino acid racemization/epimerization dating using radiocarbon-dated fossil land snails: Geology.

Goodfriend, G A and Hood, D G, 1983, Carbon isotope analysis of land snail shells: implications for carbon sources and radiocarbon dating: Radiocarbon, v 25, no. 3, p 810-830.

Goodfriend, G A and Stipp, J J, 1983, Limestone and the problem of radiocarbon dating of land-snail shell carbonate: Geology, v 11, p 575-577.

Gillespie, R, Hedges, R E M and Humm, M J, 1986, Routine AMS dating of bone and shell proteins, in Stuiver, $M$ and Kra, R S, eds, Internat ${ }^{14} \mathrm{C}$ conf, 12 th, Proc: Radiocarbon, $v$ 28 , no. 2 A, p 451-456.

Heller, J, 1982, Natural history of Theba pisana in Israel (Pulmonata: Helicidae): Jour Zool, London, v 196, p 475-487.

Heller, J and Volokita, M, 1981, Gene regulation of shell banding in a land snail from Israel: Biol Jour Linnean Soc, v 16, p 261-277.

Magaritz, M, 1986, Environmental changes recorded in the Upper Pleistocene along the desert boundary, southern Israel: Palaeogeog Palaeoclim Palaeoecol, v 53, p 213-229.

Segl, M, Levin, I, Schoch-Fischer, H. Münnich, M, Kromer, B, Tschiersch, J and Münnich, $\mathrm{K} \mathrm{O}, 1983$, Anthropogenic ${ }^{14} \mathrm{C}$ variations, in Stuiver, $\mathrm{M}$ and $\mathrm{Kra}$, R S, eds, Internatl ${ }^{14} \mathrm{C}$ conf, 11 th, Proc: Radiocarbon, v 25, no. 2, p 583-592.

Stuiver, M, 1982, The history of the atmosphere as recorded by carbon isotopes, in Goldberg, E D, ed, Atmospheric chemistry: Berlin, Springer-Verlag, p 159-179.

Stuiver, $\mathrm{M}$ and Polach, H A, 1977, Discussion: Reporting of ${ }^{14} \mathrm{C}$ data: Radiocarbon, v 19, no. 3 , p 355-363.

Tamers, M A, 1970, Validity of radiocarbon dates on terrestrial snail shells: Am Antiquity, v 35 , p $94-100$. 